\title{
Pengaruh Suhu dan Lama Pengeringan Terhadap Karakteristik Teh Herbal Matcha Daun Tenggulun (Protium javanicum Burm.F.)
}

\section{The Effect of Temperature and Drying Time on Characteristics of Tenggulun Leaf Matcha Herbal Tea (Protium javanicum Burm.F.)}

\author{
Yohanna Mei Sarah Purba', Ni Luh Ari Yusasrini ${ }^{1 *}$, Komang Ayu Nocianitri ${ }^{1}$ \\ Program Studi Teknologi Pangan, Fakultas Teknologi Pertanian, Universitas Udayana \\ Kampus Bukit Jimbaran, Badung-Bali \\ *Penulis korespondensi: Ni Luh Ari Yusasrini, Email: ariyusasrini@unud.ac.id
}

\begin{abstract}
The purpose of this research were to determine the temperature and duration of dried time on characteristics of the matcha herbal tenggulun leaves tea, as well as to determine the appropriate temperature and dried time to produce matcha herbal tenggulun leaves tea with the best characteristics. Experimental design that used on this research was Completely Randomized Design (CRD) with factorial pattern. This research was repeated 2 times so obtained 18 trial units. The parameters observed in this research were : water content, the total amount of flavonoid, fenol, and tannin, antioxidants activity based on $\mathrm{IC}_{50}$, The result of this research showed that temperature and drying time of tenggulun leaf matcha herbal tea had a significant effect on water content, the total amount of flavonoid, fenol, tannin, and antioxidants activity based on $\mathrm{IC}_{50}$ and affects of color, aroma, and overall acceptance. The best characteristic matcha herbal tenggulun leaves tea resulted from dried process at $60^{\circ} \mathrm{C}$ for 120 minutes with the total amount of flavonoid $0.64 \mathrm{mg} \mathrm{QE} / \mathrm{g}$, total amount of fenol $9.61 \mathrm{mg} \mathrm{GAE} / \mathrm{g}$, total amount of tannin $4.52 \mathrm{mg}$ TAE$/ \mathrm{g}$, and antioxidants activity based on $\mathrm{IC}_{50} 1253.99$ ppm, green color, somewhat preferred aroma, and overall acceptance liked.
\end{abstract}

Keywords: antioxidant activity, matcha tea, tenggulun leaf

\section{PENDAHULUAN}

Teh herbal merupakan minuman yang berasal dari tumbuhan herbal yang terbuat dari akar, batang, bunga, daun, biji dan kulit buah dari tanaman yang memiliki manfaat sebagai tanaman obat, mudah larut dalam air panas dan mudah dalam penyajiannya serta tidak mengandung kafein (Wahyuningsih,2011). Teh herbal dari daun mempunyai manfaat bagi kesehatan karena kandungan yang ada di dalam daun mempunyai manfaat terhadap kesehatan. Salah satu tumbuhan yang dapat dimanfaatkan sebagai teh herbal adalah daun tenggulun.

Tenggulun (Protium javanicum Burm.F.) merupakan tumbuhan yang sering dimanfaatkan sebagai obat alternative karena mempunyai khasiat yang ampuh. Kulit batang sering digunakan sebagai parem, daun dan akar sering digunakan sebagai jamu untuk obat diare. Daun dan buah tenggulun juga berkhasiat untuk perut nyeri, kurang nafsu makan dan obat batuk. Beberapa daerah di Bali, pucuk daun tenggulun biasanya digunakan sebagai sayuran dan campuran pelengkap bumbu lawar dan betutu. Daun tenggulun mengandung senyawa golongan terpenoid, steroid, flavonoid, tannin, dan minyak atsiri (Eniek,1997). Menurut Heyne (1987), kekhasan dari daun tenggulun adalah berbau asam dan mengandung minyak yang mudah menguap. Daun tenggulun memiliki peran terapeutik dalam pengobatan dan pencegahan suatu penyakit, seperti 
sebagai antioksidan, antibakteri, antidiabetes, dan antiinflamasi.

Daun tenggulun selain dikonsumsi sebagai sayuran dapat juga dikonsumsi dalam bentuk lain yaitu sebagai teh. Salah satu jenis teh yang bisa dikembangkan dari daun tenggulun adalah adalah teh matcha. Teh matcha merupakan salah satu teh yang berbentuk bubuk (ground powder) yang sering digunakan saat upacara ritual di Cina dan Jepang. Teh matcha dikonsumsi dengan mengaduknya dalam air panas dengan kocokan khusus (chasen) didalam sebuah mangkuk sampai berbusa. Keuntungan mengkonsumsi teh matcha adalah senyawa-senyawa dalam teh yang tidak larut dalam air seperti berbagai vitamin larut lemak, serat makanan yang tidak larut air, klorofil, protein, dan lain-lain akan dapat dicerna tubuh.

Pengolahan teh herbal matcha daun tenggulun mengacu pada pengolahan teh hijau jepang dengan menggunakan metode steaming. Steaming adalah proses pengukusan dengan menggunakan waktu yang singkat kurang dari 3 menit dengan suhu $90-100^{\circ} \mathrm{C}$. Felicia et.al. (2016) melaporkan, proses pengolahan teh herbal daun alpukat dengan metode pengukusan (steaming) menghasilkan teh herbal matcha daun alpukat dengan karakteristik yang lebih baik dibandingkan dengan metode penyangraian (pan firing).

Salah satu faktor yang berpengaruh dalam pengolahan teh herbal adalah suhu dan waktu pengeringan. Pengeringan pada pengolahan teh menjadi tolak ukur yang menentukan mutu teh. Karakteristik teh yang baik adalah jika suhu dan lama pengeringan yang dilakukan tepat, tanpa membuat terjadinya proses fermentasi pada the.
Suhu yang terlalu tinggi akan membuat daun teh hangus dan dapat mengurangi kandungan gizi pada teh, sedangkan suhu rendah menyebabkan proses fermentasi masih bisa berlangsung. Demikian juga halnya dengan waktu pengeringan yang terlalu lama akan mengakibatkan teh menjadi gosong, sedangkan pengeringan terlalu cepat menyebabkan kadar air masih tinggi. Menurut Liliana (2005), suhu pengeringan teh herbal berkisar antara 30$90^{\circ} \mathrm{C}$, tetapi suhu yang terbaik adalah tidak melebihi $60^{\circ} \mathrm{C}$. Lingganingrum et.al. (2018) melaporkan pengeringan teh hijau dari daun ashibata menggunakan suhu $60^{\circ} \mathrm{C}$ diperoleh nilai EC50 sebesar 23,528 ppm yang memiliki daya antioksidan tergolong sangat kuat, serta menghasilkan warna hijau tua kekuningan, aroma dan rasa khas daun ashibata segar, dan memiliki tekstur halus serta berbentuk bubuk. Penelitian Adri et.al. (2013) melaporkan pada pengeringan teh daun sirsak lama pengeringan 150 menit menghasilkan teh daun sirsak dengan aktivitas antioksidan tertinggi yaitu 76,06\% dan nilai EC50 terendah yaitu $82,16 \mu \mathrm{g} / \mathrm{mL}$, serta memiliki nilai organoleptik yang rendah. Oleh karena itu, tujuan penelitian ini adalah untuk mengetahui pengaruh suhu dan lama pengeringan terhadap karakteristik teh herbal matcha daun tenggulun dan untuk mengetahui suhu dan lama pengeringan yang tepat untuk menghasilkan teh herbal matcha daun tenggulun dengan karakterisik terbaik.

\section{METODE PENELITIAN}

\section{Tempat dan Waktu Penelitian}

Penelitian ini dilaksanakan di Laboratorium Analisis Pangan, Laboratorium Pengolahan 
Pangan, dan Laboratorium Rekayasa Pangan, Fakultas Teknologi Pertanian Universitas Udayana. Penelitian ini dilakukan pada bulan Januari - Maret 2020.

\section{Bahan dan Alat}

Bahan yang digunakan dalam penelitian ini mencakup bahan utama dan bahan kimia. Bahan utama pada penelitian ini adalah daun tenggulun (Protium javanicum Burm.F.) yang diperoleh di kawasan Bukit Jimbaran, Bali. Daun tenggulun yang digunakan adalah daun muda p-2 dan p-3 yang memiliki tekstur halus dan lentur. Bahan kimia yang digunakan terdiri dari etanol PA, akuades, DPPH (Sigma-Aldrich), standar kuersetin (Sigma-Aldrich), standar asam galat (SigmaAldrich), asam tanat (Sigma-Aldrich), folinciocalteau (MERCK), follin denis (MERCK) $\mathrm{Na}_{2} \mathrm{CO}_{3}$ (MERCK), dan $\mathrm{AlCl}_{3}$ (MERCK)

Alat-alat yang digunakan dalam penelitian ini adalah oven (MKS-FDH10), blender (Philips), ayakan 100 mesh, kuas, alumunium foil, spektrofotometer (Genesys 10S UV-Vis, Amerika Serikat), timbangan analitik (Shimadzu ATY224, Jerman), timbangan analitik (Sartorius MSA 2255100-DU), vortex, pipet tetes, pipet mikro, tabung reaksi, tabung centifuse, rak tabung reaksi, corong kaca (Pyrex, Jepang), labu ukur, gelas beaker (Pyrex, Jepang), tabung sentrifugasi, alat sentrifugasi (Damon IEC Division, Amerika Serikat), kompor listrik, tabung ukur, pipet ukur, loyang aluminum, rubber bulb, botol amber, cawan alumunium, pinset, spatula, kuvet, dan desikator.

\section{Rancangan Percobaan}

Rancangan yang digunakan dalam penelitian ini adalah Rancangan Acak Lengkap
(RAL) dengan pola faktorial yang terdiri dari 2 faktor sebagai berikut:

Faktor pertama adalah suhu perngeringan (S) yang terdiri dari 3 taraf yaitu:

$\mathrm{S} 1=$ Pengeringan dengan suhu $50^{\circ} \mathrm{C}$

$\mathrm{S} 2=$ Pengeringan dengan suhu $60^{\circ} \mathrm{C}$

$\mathrm{S} 3=$ Pengeringan dengan suhu $70^{\circ} \mathrm{C}$.

Faktor kedua adalah waktu pengeringan $(\mathrm{T})$ yang terdiri dari 3 taraf yaitu:

$\mathrm{T} 1=$ Pengeringan dengan waktu 90 menit

$\mathrm{T} 2=$ Pengeringan dengan waktu 120 menit

$\mathrm{T} 3=$ Pengeringan dengan waktu 150 menit

Perlakuan diulang sebanyak 2 kali sehinggaa diperoleh 18 unit percobaan. Data dianalisis dengan sidik ragam dan apabila perlakuan berpengaruh nyata terhadap variabel yang diamati, dilanjutkan dengan uji Duncan's Multiple Range Test (DMRT) dengan tingkat signifikasnsi $\mathrm{P}<0,05$ dan data hasil uji evaluasi sensoris dianalisis dengan menggunakan uji friedman dengan membandingkan nilai p.value $<0,05$.

\section{Pelaksanaan Penelitian}

\section{Pembuatan bubuk teh herbal matcha daun tenggulun}

Daun tenggulun yang telah disortir kemudian dikukus (steaming) dengan menggunakan suhu $90-100^{\circ} \mathrm{C}$ selama 90 detik, selanjutnya didinginkan selama 5 menit dan disusun di loyang yang telah diberi alas aluminium foil. Daun tenggulun yang telah di susun di keringkan dalam oven dengan suhu pengeringan $50^{\circ} \mathrm{C}, 60^{\circ} \mathrm{C}$, dan $70^{\circ} \mathrm{C}$ dan waktu pengeringan 1,5 jam, 2 jam, dan 2,5 jam. Daun tenggulun yang telah kering kemudian dihancurkan dengan blender lalu diayak dengan ayakan 100 mesh sehingga 
menghasilkan bubuk teh herbal matcha daun tenggulun. Bubuk teh herbal matcha daun tenggulun kemudian dimasukkan ke dalam wadah yang dibungkus dengan aluminium foil. Proses pembuatan bubuk teh herbal matcha daun tenggulun dapat dilihat pada Gambar 1.

\section{Proses pembuatan seduhan teh herbal matcha daun tenggulun}

Proses penyeduhan teh herbal matcha daun tenggulun menggunakan metode yang dilakukan oleh Gromer (2009) yaitu sebanyak 1 gram bubuk matcha daun tenggulun dimasukkan kedalam gelas dan dilarutkan dengan air hangat bersuhu $80^{\circ} \mathrm{C}$ sebanyak $80 \mathrm{ml}$. Teh diaduk dengan menggunakan alat pengaduk teh yang dinamakan dengan chasen atau dengan milk fronther hingga mengeluarkan busa dan homogen.

\section{Parameter yang diamati}

Parameter yang diamati pada penelitian ini adalah: kadar air dengan menggunakan metode pengeringan Sudarmadji et.al. (1997), kadar total flavonoid (Rahman et.al. (2006), kadar total fenol Sakanaka et.al. (2003), kadar total tanin Suhardi (1997), penentuan aktivitas antioksidan dilakukan dengan metode 2,2-dhyphenyl-1 picrylhydrazyl (DPPH) Shah dan Modi (2015), dan sifat sensoris teh herbal matcha daun tenggulun dilakukan dengan menggunakan uji hedonik (kesukaan) dan uji skoring berdasarkan Soekarto (1985).

\section{HASIL DAN PEMBAHASAN}

\section{Kadar Air}

Hasil analisis kadar air teh herbal matcha daun tenggulun dapat dilihat pada Tabel 1 .

Tabel 1. Nilai rata-rata kadar air (\%) teh herbal matcha daun tenggulun dengan perlakuan suhu dan lama pengeringan

\begin{tabular}{cccc}
\hline \multirow{2}{*}{ Lama Pengeringan } & \multicolumn{3}{c}{ Suhu pengeringan } \\
\cline { 2 - 4 } & $50^{\circ} \mathrm{C}(\mathrm{S} 1)$ & $60^{\circ} \mathrm{C}(\mathrm{S} 2)$ & $70^{\circ} \mathrm{C}(\mathrm{S} 3)$ \\
\hline 90 menit (T1) & $11,09 \pm 0,01 \mathrm{a}$ & $10,87 \pm 0,08 \mathrm{a}$ & $9,38 \pm 0,06 \mathrm{~b}$ \\
& $\mathrm{a}$ & $\mathrm{a}$ & $\mathrm{a}$ \\
120 menit (T2) & $10,98 \pm 0,23 \mathrm{a}$ & $9,89 \pm 0,12 \mathrm{~b}$ & $8,78 \pm 0,11 \mathrm{c}$ \\
& $\mathrm{a}$ & $\mathrm{b}$ & $\mathrm{b}$ \\
150 menit (T3) & $10,69 \pm 0,25 \mathrm{a}$ & $9,31 \pm 0,03 \mathrm{~b}$ & $8,26 \pm 0,04 \mathrm{c}$ \\
& $\mathrm{b}$ & $\mathrm{c}$ & $\mathrm{c}$ \\
\hline
\end{tabular}

Keterangan: Nilai rata-rata \pm standar deviasi $(\mathrm{n}=2)$. Huruf yang sama pada baris dan kolom yang sama menunjukkan perlakuan tidak berbeda nyata $(\mathrm{P}>0,05)$.Notasi huruf dibelakang nilai rata-rata dilihat per baris sedangkan notasi huruf dibawah nilai rata-rata dilihat per kolom.

Hasil sidik ragam menunjukkan bahwa interaksi antara suhu dan lama pengeringan daun tenggulun berpengaruh sangat nyata $(\mathrm{P}<0,01)$ terhadap kadar air teh herbal matcha daun tenggulun. Tabel 1 menunjukkan, kadar air (\%bb) teh herbal matcha daun tenggulun berkisar antara $8,26 \%$ hingga $11,09 \%$. Kadar air terendah diperoleh pada suhu $70^{\circ} \mathrm{C}$ selama 150 menit yaitu $8,26 \%$ dan kadar air tertinggi diperoleh pada suhu $50^{\circ} \mathrm{C}$ selama 90 menit yaitu $11,09 \%$. Hasil penelitian menunjukkan bahwa suhu dan lama pengeringan yang tinggi akan menghasilkan kadar air yang rendah. Felicia et.al. (2016), melaporkan bahwa makin tinggi suhu udara pengering, makin 
besar energi panas yang dibawa udara sehingga makin banyak jumlah massa cairan yang diuapkan. Kemampuan bahan untuk melepaskan air dari permukaannya juga akan semakin besar dengan meningkatnya suhu udara pengering yang digunakan. Hal ini sejalan dengan pernyataan Taib et.al. (1997) yang melaporkan bahwa meningkatnya kemampuan suatu bahan untuk melepaskan air dari permukaannya seiring dengan meningkatnya suhu udara pengering.

Waktu pengeringan juga berpengaruh terhadap kadar air teh herbal matcha daun tenggulun. Semakin lama waktu pengeringan yang diberikan akan membuat panas yang diterima bahan akan semakin banyak sehigga jumlah air yang diuapkan pada bahan pangan semakin banyak dan mengakibatkan kadar air semakin rendah
(Winarno, 1995). Setiap kenaikan suhu dan waktu pengeringan yang diberikan akan memberikan pengaruh yang sangat nyata terhadap perpindahan air pada bahan (Riansyah et.al. (2013).

Berdasarkan standar pengujian SNI 033836-2012 kadar air teh hijau bubuk maksimal adalah $8 \%$, sehingga kadar air teh herbal matcha yang dikeringkan pada suhu $70^{\circ} \mathrm{C}$ selama 120 menit dan pada suhu $70^{\circ} \mathrm{C}$ selama 150 menit sudah memenuhi standar yang ditetapkan, sedangkan perlakuan yang lainnya belum memenuhi standar pengujian SNI dikarenakan kadar air yang diperoleh masih diatas $8 \%$.

\section{Kadar Total Flavonoid}

Hasil analisis kadar total flavonoid teh herbal matcha daun tenggulun dapat dilihat pada Tabel 2.

Tabel 2. Nilai rata-rata kadar total flavonoid (mg QE/g) teh herbal matcha daun tenggulun dengan perlakuan suhu dan lama pengeringan

\begin{tabular}{cccc}
\hline \multirow{2}{*}{ Lama Pengeringan } & \multicolumn{3}{c}{ Suhu pengeringan } \\
\cline { 2 - 4 } & $50^{\circ} \mathrm{C}(\mathrm{S} 1)$ & $60^{\circ} \mathrm{C}(\mathrm{S} 2)$ & $70^{\circ} \mathrm{C}(\mathrm{S} 3)$ \\
\hline 90 menit (T1) & $0,51 \pm 0,01 \mathrm{~b}$ & $0,61 \pm 0,003 \mathrm{a}$ & $0,61 \pm 0,006 \mathrm{a}$ \\
& $\mathrm{c}$ & $\mathrm{b}$ & $\mathrm{a}$ \\
\multirow{2}{*}{120 menit (T2) } & $0,54 \pm 0,0007 \mathrm{c}$ & $0,64 \pm 0,005 \mathrm{a}$ & $0,59 \pm 0,001 \mathrm{~b}$ \\
& $\mathrm{~b}$ & $\mathrm{a}$ & $\mathrm{b}$ \\
\multirow{2}{*}{150 menit (T3) } & $0,57 \pm 0,003 \mathrm{~b}$ & $0,63 \pm 0,003 \mathrm{a}$ & $0,57 \pm 0,001 \mathrm{~b}$ \\
& $\mathrm{a}$ & $\mathrm{a}$ & $\mathrm{c}$ \\
\hline
\end{tabular}

Keterangan: Nilai rata-rata \pm standar deviasi $(\mathrm{n}=2)$. Huruf yang sama pada baris dan kolom yang sama menunjukkan perlakuan tidak berbeda nyata $(\mathrm{P}>0,05)$.Notasi huruf dibelakang nilai rata-rata dilihat per baris sedangkan notasi huruf dibawah nilai rata-rata dilihat per kolom.

Hasil analisis ragam menunjukkan bahwa interaksi antara suhu dan lama pengeringan daun tenggulun berpengaruh sangat nyata $(\mathrm{P}<0,01)$ terhadap kadar total flavonoid teh herbal matcha daun tenggulun. Tabel 2 menunjukkan bahwa kadar total flavonoid tertinggi pada teh herbal matcha daun tengggulun diperoleh pada suhu $60^{\circ} \mathrm{C}$ selama 120 menit yaitu $0,64 \mathrm{mg}$ QE/g yang tidak berbeda dengan pengeringan suhu $60^{\circ} \mathrm{C}$ selama 150 menit dan suhu $70^{\circ} \mathrm{C}$ selama 90 menit, Kadar total flavonoid terendah diperoleh pada pengeringan teh herbal matcha daun tenggulun suhu $50^{\circ} \mathrm{C}$ selama 90 menit yaitu $0,51 \mathrm{mg}$ QE/g. Semakin tinggi suhu yang disertai waktu pemanasan yang semakin lama 
akan mengakibatkan senyawa flavonoid mengalami kerusakan. Menurut Lenny (2006) dalam penelitian Felicia et.al. (2013), menjelaskan bahwa senyawa flavonoid bersifat tidak tahan panas dan mudah teroksidasi pada suhu yang tinggi. Semakin tinggi suhu dan lama pemanasan maka flavonoid akan semakin menurun. Perlakuan pemanasan pada bahan dapat menyebabkan keluarnya beberapa senyawa fenolik dengan berat molekul rendah, dimana flavonoid yang terdapat pada teh merupakan senyawa fenolik yang memiliki berat molekul rendah ( Jeong et.al., 2004). Nathaniel et.al. (2019) juga melaporkan bahwa kadar total flavonoid teh herbal celup daun rambusa mulai mengalami penurunan pada suhu $60^{\circ} \mathrm{C}$ dan waktu pengeringan $3,5 \mathrm{jam}$.

\section{Kadar Total Fenol}

Hasil analisis kadar total fenol teh herbal matcha daun tenggulun dapat dilihat pada Tabel 3.

Tabel 3. Nilai rata-rata kadar total fenol (mg GAE/g) teh herbal matcha daun tenggulun dengan perlakuan suhu dan lama pengeringan

\begin{tabular}{cccc}
\hline \multirow{2}{*}{ Lama Pengeringan } & \multicolumn{3}{c}{ Suhu pengeringan } \\
\cline { 2 - 4 } & $50^{\circ} \mathrm{C}(\mathrm{S} 1)$ & $60^{\circ} \mathrm{C}(\mathrm{S} 2)$ & $70^{\circ} \mathrm{C}(\mathrm{S} 3)$ \\
\hline 90 menit (T1) & $8,03 \pm 0,02 \mathrm{c}$ & $9,20 \pm 0,09 \mathrm{a}$ & $9,00 \pm 0,01 \mathrm{~b}$ \\
& $\mathrm{c}$ & $\mathrm{b}$ & $\mathrm{a}$ \\
120 menit (T2) & $8,40 \pm 0,03 \mathrm{c}$ & $9,61 \pm 0,07 \mathrm{a}$ & $8,86 \pm 0,02 \mathrm{~b}$ \\
& $\mathrm{~b}$ & $\mathrm{a}$ & $\mathrm{b}$ \\
150 menit (T3) & $8,89 \pm 0,04 \mathrm{~b}$ & $9,42 \pm 0,08 \mathrm{a}$ & $8,75 \pm 0,04 \mathrm{~b}$ \\
& $\mathrm{a}$ & $\mathrm{ab}$ & $\mathrm{c}$ \\
\hline
\end{tabular}

Keterangan: Nilai rata-rata \pm standar deviasi $(\mathrm{n}=2)$. Huruf yang sama pada baris dan kolom yang sama menunjukkan perlakuan tidak berbeda nyata $(\mathrm{P}>0,05)$. Notasi huruf dibelakang nilai rata-rata dilihat per baris sedangkan notasi huruf dibawah nilai rata-rata dilihat per kolom.

Hasil analisis ragam menunjukkan bahwa interaksi antara suhu dan lama pengeringan daun tenggulun berpengaruh sangat nyata $(\mathrm{P}<0,01)$ terhadap kadar total fenol the herbal matca daun tenggulun. Tabel 3 menunjukkan bahwa kadar total fenol tertinggi pada teh herbal matcha daun tengggulun diperoleh pada suhu pengeringan $60^{\circ} \mathrm{C}$ selama 120 menit yaitu 9,61 mg GAE/g yang tidak berbeda nyata dengan suhu pengeringan $60^{\circ} \mathrm{C}$ selama 150 menit, sedangkan kadar total fenol terendah diperoleh pada suhu pengeringan $70^{\circ} \mathrm{C}$ selama 150 menit yaitu $8,75 \mathrm{mg} \mathrm{GAE} / \mathrm{g}$.
Berdasarkan pada Tabel 3, total fenol meningkat mulai dari suhu $50^{\circ} \mathrm{C}$ ke suhu $60^{\circ} \mathrm{C}$ dikarenakan kandungan fenol yang ada di dalam teh belum melewati masa optimumnya, kemudian mengalami penurunan pada suhu $70^{\circ} \mathrm{C}$ disertai dengan lama pengeringan yang semakin lama. Hal ini sesuai dengan penelitian Nathaniel et.al., (2019) mengatakan total fenol pada teh celup daun rambusa mengalami peningkatan pada suhu $50^{\circ} \mathrm{C}$ kemudian turun setelah melewati suhu optimumnya. Kadar total fenol pada teh kulit kakao menunjukkan penurunan seiring dengan meningkatnya suhu pengeringan disertai dengan 
lama pengeringan (Kusuma et.al., 2019). Total fenol pada penelitian teh herbal matcha daun tenggulun optimum pada suhu $60^{\circ} \mathrm{C}$ selama 120 menit. Semakin tinggi suhu dan lama pengeringan maka kandungan fenol akan terganggu sehingga jumlah total fenol akan mencapai puncak maksimum kemudian konstan dan cenderung mengalami penurunan (Rahmawati et.al., 2013).

\section{Kadar Total Tanin}

Hasil analisis kadar total tanin teh herbal matcha daun tenggulun dapat dilihat pada Tabel 4.

Tabel 4. Nilai rata-rata kadar total tanin (mg TAE/g) teh herbal matcha daun tenggulun dengan perlakuan suhu dan lama pengeringan

\begin{tabular}{cccc}
\hline \multirow{2}{*}{ Lama Pengeringan } & \multicolumn{3}{c}{ Suhu pengeringan } \\
\cline { 2 - 4 } & $50^{\circ} \mathrm{C}(\mathrm{S} 1)$ & $60^{\circ} \mathrm{C}(\mathrm{S} 2)$ & $70^{\circ} \mathrm{C}(\mathrm{S} 3)$ \\
\hline 90 menit (T1) & $4,22 \pm 0,01 \mathrm{~b}$ & $4,41 \pm 0,04 \mathrm{a}$ & $3,93 \pm 0,03 \mathrm{c}$ \\
& $\mathrm{a}$ & $\mathrm{ab}$ & $\mathrm{a}$ \\
120 menit (T2) & $4,29 \pm 0,027 \mathrm{~b}$ & $4,52 \pm 0,03 \mathrm{a}$ & $3,63 \pm 0,10 \mathrm{c}$ \\
& $\mathrm{a}$ & $\mathrm{a}$ & $\mathrm{a}$ \\
150 menit (T3) & $4,33 \pm 0,0005 \mathrm{a}$ & $4,36 \pm 0,05 \mathrm{a}$ & $3,49 \pm 0,22 \mathrm{~b}$ \\
& $\mathrm{a}$ & $\mathrm{b}$ & $\mathrm{a}$ \\
\hline
\end{tabular}

Keterangan: Nilai rata-rata \pm standar deviasi $(n=2)$. Huruf yang sama pada baris dan kolom yang sama menunjukkan perlakuan tidak berbeda nyata $(\mathrm{P}>0,05)$. Notasi huruf dibelakang nilai rata-rata dilihat per baris sedangkan notasi huruf dibawah nilai rata-rata dilihat per kolom.

Hasil analisis keragaman menunjukkan bahwa interaksi antara suhu dan lama pengeringan daun tenggulun berpengaruh sangat nyata $(\mathrm{P}<0,01)$ terhadap total tanin teh herbal matcha daun tenggulun. Tabel 4 menunjukkan bahwa kadar total tanin tertinggi teh herbal matcha daun tengggulun diperoleh pada suhu pengeringan $60^{\circ} \mathrm{C}$ selama 120 menit yaitu 4,52 mg TAE/g yang tidak berbeda dengan suhu pengeringan $60^{\circ} \mathrm{C}$ selama 90 menit dan $50^{\circ} \mathrm{C}$ selama 150 menit, sedangkan kadar total tanin terendah diperoleh pada suhu pengeringan $70^{\circ} \mathrm{C}$ selama 150 menit yaitu 3,49 mg TAE/g. Suhu dan waktu pengeringan yang tinggi akan menghasilkan total tannin yang semakin rendah. Tanin merupakan senyawa polifenol yang larut dalam air dan rentan terhadap panas. Menurut Sekarin (2011), komponen tannin akan mengalami banyak perubahan kimia apabila dikenai suhu dan waktu pengeringan yang tinggi. Hasil penelitian ini serupa dengan yang dilaporkan Sari et.al. (2020) bahwa suhu dan lama pengeringan yang tinggi pada teh daun tin menghasilkan nilai kadar tannin yang semakin rendah.

\section{Aktivitas Antioksitas berdasarkan $\mathrm{IC}_{\mathbf{5 0}}$}

Hasil analisis aktivitas antioksidan berdasarkan $\mathrm{IC}_{50}$ teh herbal matcha daun tenggulun dapat dilihat pada Tabel 5.

Hasil analisis ragam menunjukkan bahwa interaksi antara suhu dan lama pengeringan daun tenggulun berpengaruh sangat nyata $(\mathrm{P}<0,01)$ terhadap aktivitas antioksidan berdasarkan $\mathrm{IC}_{50}$ Teh herbal matcha daun tenggulun. Tabel 5 menunjukkan bahwa $\mathrm{IC}_{50}$ terbaik pada teh herbal 
matcha daun tengggulun diperoleh pada suhu $60^{\circ} \mathrm{C}$ selama 120 menit yaitu 1253,99 ppm.

Pada suhu tinggi dan waktu pengeringan yang lama menunjukkan terjadinya peningkatan nilai $\mathrm{IC}_{50}$ pada teh herbal matcha daun tenggulun. Semakin rendah nilai $\mathrm{IC}_{50}$ suatu bahan menunjukkan kemampuan bahan tersebut untuk menghambat radikal bebas semakin tinggi. Menurut Widarta et.al. (2018) penghambatan radikal DPPH sangat terkait dengan data kadar total fenolik, total flavonoid, dan total tannin yang diperoleh. Semakin tinggi total fenol, total flavonoid, dan total tannin maka penghambatan radikal DPPH-nya juga semakin meningkat, demikian pula sebaliknya. Serupa dengan pernyataan Widarta dan Arnata (2017) menyatakan bahwa terdapat korelasi positif antara total fenolik, total flavonoid dan total tannin terhadap aktivitas antioksidan. Berdasarkan Tabel 5, nilai $\mathrm{IC}_{50}$ pada teh matcha herbal daun tenggulun memiliki intesitas sangat tinggi tetapi aktivitas antioksidan yang sangat rendah.

Tabel 5. Nilai rata-rata aktivitas antioksidan berdasarkan $\mathrm{IC}_{50}(\mathrm{ppm})$ teh herbal matcha daun tenggulun dengan perlakuan suhu dan lama pengeringan

\begin{tabular}{cccc}
\hline \multirow{2}{*}{ Lama Pengeringan } & \multicolumn{3}{c}{ Suhu pengeringan } \\
\cline { 2 - 4 } & $50^{\circ} \mathrm{C}(\mathrm{S} 1)$ & $60^{\circ} \mathrm{C}(\mathrm{S} 2)$ & $70^{\circ} \mathrm{C}(\mathrm{S} 3)$ \\
\hline 90 menit (T1) & $1452,83 \pm 0,04 \mathrm{c}$ & $1306,83 \pm 0,46 \mathrm{a}$ & $1338,96 \pm 0,18 \mathrm{~b}$ \\
& $\mathrm{c}$ & $\mathrm{b}$ & $\mathrm{a}$ \\
120 menit (T2) & $1417,28 \pm 0,26 \mathrm{c}$ & $1253,99 \pm 0,72 \mathrm{a}$ & $1378,84 \pm 0,84 \mathrm{~b}$ \\
& $\mathrm{~b}$ & $\mathrm{a}$ & $\mathrm{b}$ \\
150 menit (T3) & $1368,14 \pm 1,32 \mathrm{~b}$ & $1275,46 \pm 0,46 \mathrm{a}$ & $1432,77 \pm 0,64 \mathrm{~b}$
\end{tabular}

Keterangan: Nilai rata-rata \pm standar deviasi $(n=2)$. Huruf yang sama pada baris dan kolom yang sama menunjukkan perlakuan tidak berbeda nyata $(\mathrm{P}>0,05)$. Notasi huruf dibelakang nilai rata-rata dilihat per baris sedangkan notasi huruf dibawah nilai rata-rata dilihat per kolom.

Hubungan Antara Total Flavonoid, Total Fenol, dan Total Tanin Terhadap Aktivitas Antioksidan Berdasarkan $\mathrm{IC}_{50}$

Pada penelitian teh herbal matcha daun tenggulun, hasil total flavonoid, total fenol, dan total tannin memiliki korelasi positif terhadap aktivitas antioksidan berdasarkan $\mathrm{IC}_{50}$. Hubungan antara total flavonoid, total fenol, dan total tannin dapat dilihat pada Gambar 2, Gambar 3, dan Gambar 4. Gambar tersebut menunjukkan hubungan antara nilai kadar total (sumbu Y) dengan aktivitas antioksidan berdasarkan $\mathrm{IC}_{50}$ (sumbu X). Berdasarkan Gambar 2, 3, dan 4 koefisien korelasi $\left(\mathrm{R}^{2}\right)$ antara total flavonoid dengan aktivitas antioksidan berdasarkan $\mathrm{IC}_{50}$ teh matcha herbal daun tenggulun yaitu 0,8661, sementara koefisien korelasi $\left(\mathrm{R}^{2}\right)$ antara total fenol dengan aktivitas antioksidan berdasarkan $\mathrm{IC}_{50}$ teh matcha herbal daun tenggulun yaitu 0,8926 dan koefisien korelasi $\left(\mathrm{R}^{2}\right)$ antara total tannin dengan aktivitas antioksidan berdasarkan $\mathrm{IC}_{50}$ teh matcha herbal daun tenggulun yaitu 0,2828 . 
Menurut Sarwono (2006) mengatakan koefisien korelasi $\left(\mathrm{R}^{2}\right)$ mempunyai nilai lebih besar dari 0,75-0,99 dapat dikategorikan korelasi sangat kuat. Semakin tinggi nilai koefisien korelasi maka semakin tinggi tingkat keeratan antara kedua variable (Simamora et.al.,2020). Berdasarkan data yang diperoleh dapat disimpulkan bahwa aktivitas antioksidan berdasarkan $\mathrm{IC}_{50}$ pada teh herbal matcha daun tenggulun dipengaruhi oleh total fenol yaitu dengan nilai koefisien $\left(\mathrm{R}^{2}\right)$ 0,8926. Sampel teh yang memiliki aktivitas antioksidan tinggi memiliki total fenol yang tinggi, sedangkan sampel teh yang memiliki aktivitas antioksidan rendah memiliki total fenol yang rendah (Indarwati, 2015). Hal ini sesuai dengan penelitian Atmaja (2011), menyatakan bahwa semakin tinggi kandungan fenolik maka akan memberikan aktiviras antioksidan yang semakin besar.

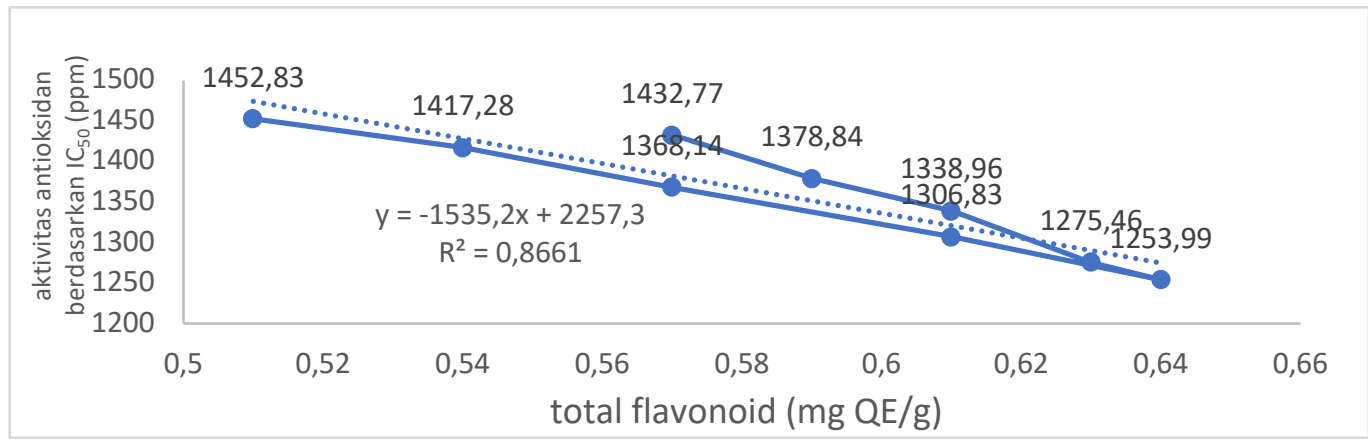

Gambar 2.Grafik hubungan antara total flavonoid dengan aktivitas antioksidan berdasarkan IC $_{50}$

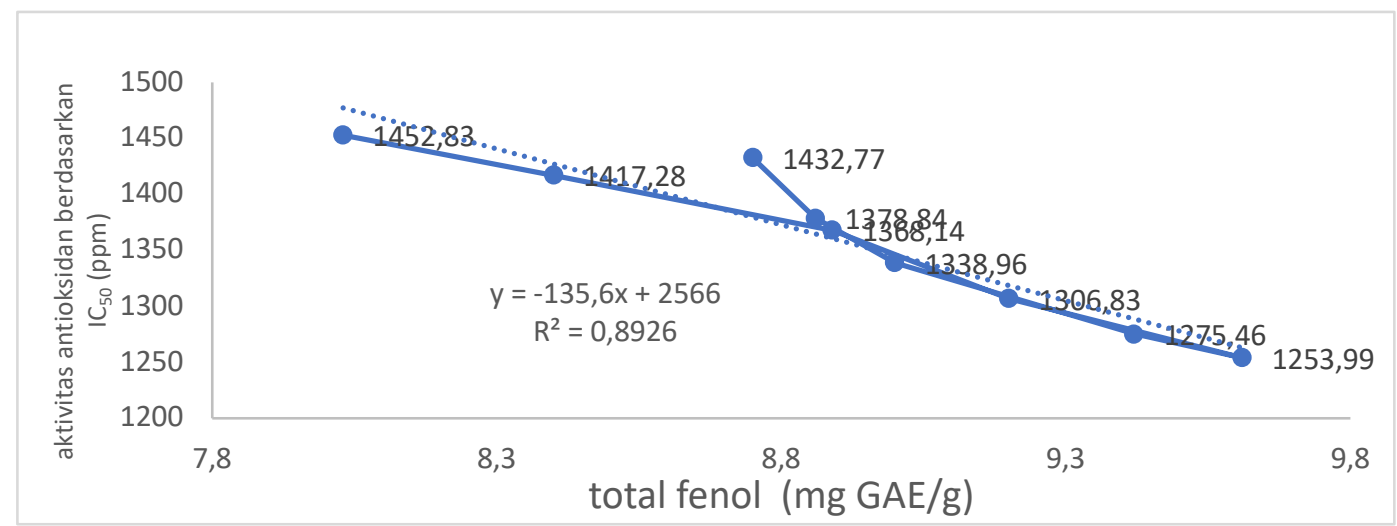

Gambar 3.Grafik hubungan antara total fenol dengan aktivitas antioksidan berdasarkan IC $_{50}$

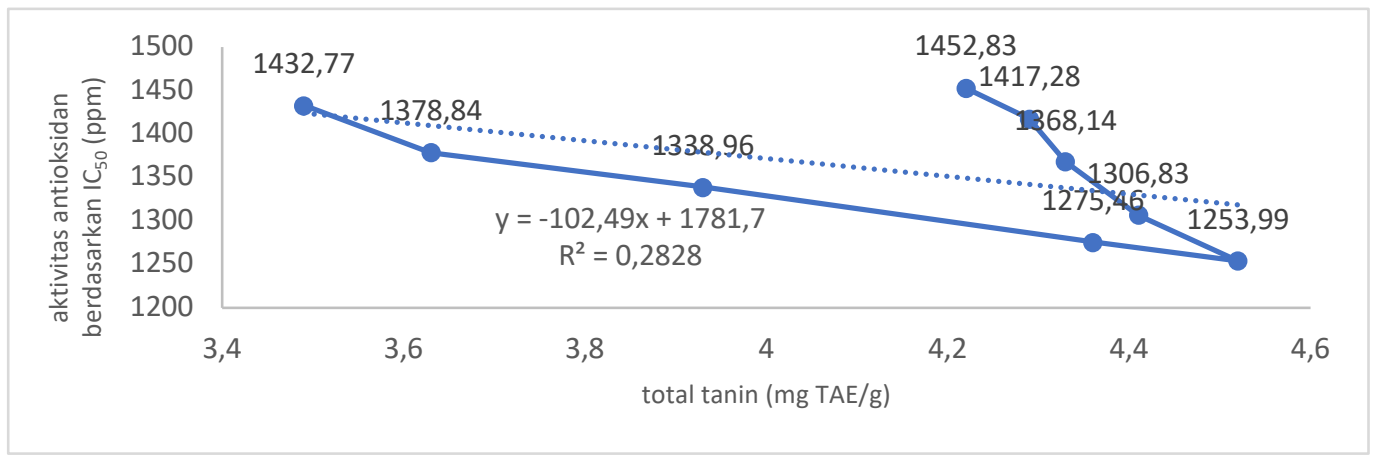

Gambar 4.Grafik hubungan antara total tanin dengan aktivitas antioksidan berdasarkan $\mathrm{IC}_{50}$ 


\section{Sifat Sensoris}

Pengujian Sifat sensoris teh herbal matcha daun tenggulun dilakukan oleh 25 panelis semi terlatih. Parameter yang diuji meliputi warna, aroma, rasa, dan penerimaan keseluruhan. Evaluasi sensoris menggunakan uji hedonik (kesukaan) dan uji skoring. Uji hedonik dilakukan terhadap warna, aroma, rasa, dan penerimaan keseluruhan sedangkan uji skoring dilakukan terhadap warna. Hasil rata-rata penilaian panelis terhadap karakteristik sensoris teh herbal matcha daun tenggulun dapat dilihat pada Tabel 6 .

Tabel 6. Nilai rata-rata hasil uji organoleptik teh herbal matcha daun tenggulun

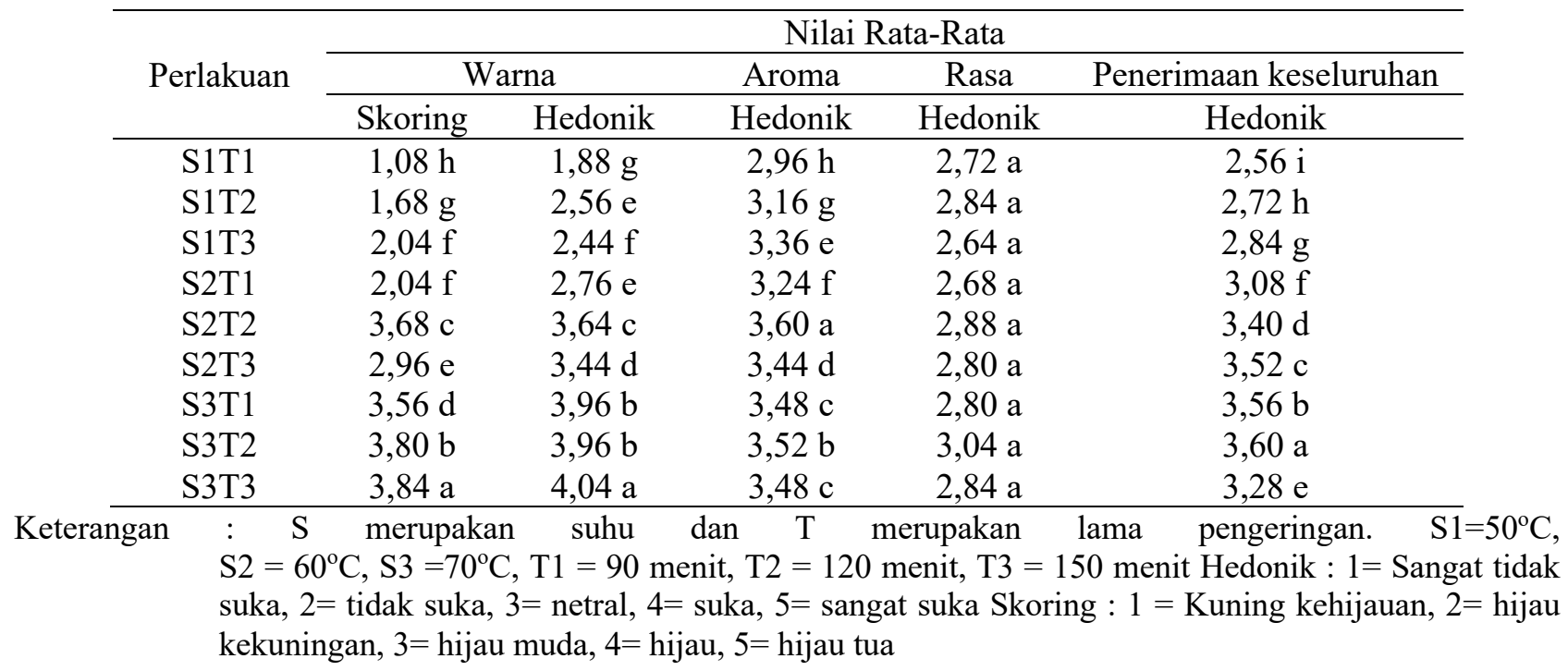

\section{Warna}

Hasil uji friedman pada warna teh herbal matcha daun tenggulun terdapat perbedaan secara signifikan dengan nilai $\mathrm{p}=0,00 \quad(\mathrm{p}$. value $<0,05)$ pada uji skoring dan uji hedonic. Tabel 6 menunjukkan nilai rata-rata warna teh herbal matcha daun tenggulun dengan uji skoring tertinggi diperoleh pada perlakuan suhu pengeringan $70^{\circ} \mathrm{C}$ selama 150 menit yaitu 3,84 dengan kriteria warna teh matcha hijau dan uji skoring terendah di peroleh pada suhu pengeringan $50^{\circ} \mathrm{C}$ selama 90 menit yaitu 1,08 dengan kriteria warna teh matcha kuning kehijauan. Uji hedonik warna teh tertinggi diperoleh pada perlakuan suhu $70^{\circ} \mathrm{C}$ selama 150 menit yaitu 4,04 dengan kriteria suka dan uji hedonik terendah diperoleh pada suhu $50^{\circ} \mathrm{C}$ selama 90 menit yaitu 1,88 dengan kriteria tidak suka.

Adanya proses pengeringan yang dilakukan pada teh herbal matcha daun tenggulun mengakibatkan terjadinya proses oksidasi enzimatis Semakin tinggi suhu disertai semakin lama waktu pengeringan akan membuat enzim polifenol oksidasise inaktif sehingga warna air seduhan masih memiliki warna kehijauan sedangkan suhu rendah disertai dengan waktu yang singkat menyebabkan enzim polifenol oksidasi masih aktif dan membuat warna air seduhan 
teroksidasi menjadi warna coklat (Nathaniel et.al.,2019) Tujuan dari oksidasi adalah memperoleh sifat-sifat karakteristik teh yang dikehendaki yaitu salah satunya warna air seduhan. (Setyamidjaja, 2000).

\section{Rasa}

Hasil uji friedman pada uji hedonik rasa teh herbal matcha daun tenggulun tidak terdapat perbedaan secara signifikan dengan nilai $p=0,69$ (p.value $>0,05$ ). Tabel 6 menunjukkan nilai ratarata rasa teh herbal matcha daun tenggulun dengan uji hedonik tertinggi diperoleh pada perlakuan suhu $70^{\circ} \mathrm{C}$ selama 120 menit yaitu 3,04 dengan kriteria suka dan uji hedonik terendah diperoleh pada suhu $50^{\circ} \mathrm{C}$ selama 150 menit yaitu 2,72 dengan kriteria netral. Teh herbal matcha daun tenggulun memiliki rasa agak pahit (sepat). Rasa pahit yang terkandung pada teh herbal matcha daun tenggulun di peroleh dari polifenol berupa katekin.

\section{Aroma}

Hasil uji friedman pada uji hedonik aroma teh herbal matcha daun tenggulun terdapat perbedaan secara signifikan dengan nilai $\mathrm{p}=0,003$ (p.value $<0,05$ ). Tabel 6 menunjukkan nilai ratarata aroma teh herbal matcha daun tenggulun dengan uji hedonik tertinggi diperoleh pada perlakuan suhu pengeringan $60^{\circ} \mathrm{C}$ selama 120 menit yaitu 3,60 dengan kriteria suka dan uji hedonik terendah diperoleh pada suhu pengeringan $50^{\circ} \mathrm{C}$ selama 90 menit yaitu 2,96 dengan kriteria netral.

Aroma yang khas dari daun tenggulun dapat dirasakan oleh indera penciuman panelis. Peran aroma terhadap produk dapat mempengaruhi minat konsumen untuk mencoba suatu produk makanan.
Aroma dalam suatu bahan makanan atau minuman dapat ditimbulkan oleh komponen-komponen volatile, akan tetapi komponen volatile tersebut dapat hilang selama proses pengolahan terutama terhadap panas (Fellow,1990)

\section{Penerimaan Keseluruhan}

Penerimaan keseluruhan dilakukan untuk mengetahui tingkat kesukaan panelis secara keseluruhan terhadap warna, rasa, dan aroma dari teh herbal matcha daun tenggulun. Hasil uji statistik pada uji hedonik penerimaan keseluruhan teh herbal matcha daun tenggulun terdapat perbedaan secara signifikan dengan nilai $\mathrm{p}=0,00$ (p.value $<0,05$ ).Tabel 6 menunjukkan nilai rata-rata penerimaan teh herbal matcha daun tenggulun dengan uji hedonik tertinggi diperoleh pada perlakuan suhu pengeringan $70^{\circ} \mathrm{C}$ selama 120 menit yaitu 3,60 dengan kriteria suka dan uji hedonik terendah diperoleh pada suhu pengeringan $50^{\circ} \mathrm{C}$ selama 90 menit yaitu 2,56 dengan kriteria netral. Hal ini menunjukkan panelis dapat menerima produk teh herbal matcha daun tenggulun dari segi warna, rasa, dan aroma khas daun tenggulun.

\section{KESIMPULAN DAN SARAN}

\section{Kesimpulan}

Interaksi antara suhu dan lama pengeringan pada teh herbal matcha daun tenggulun berpengaruh sangat nyata terhadap kadar air, total flavonoid, total fenol, total tannin, dan aktivitas antioksidan berdasarkan $\mathrm{IC}_{50}$. Perbedaan suhu dan lama pengeringan berpengaruh terhadap warna, aroma, dan penerimaan keseluruhan dan tidak berpengaruh terhadap rasa teh herbal matcha daun 
tenggulun. Karakteristik teh herbal matcha daun tenggulun terbaik dihasilkan dari perlakuan pengeringan pada suhu $60^{\circ} \mathrm{C}$ selama 120 menit dengan kadar total flavonoid $0,64 \mathrm{mg} \mathrm{QE} / \mathrm{g}$, total fenol 9,61 mg GAE/g, total tannin 4,52mg TAE/g, dan aktivitas antioksidan berdasarkan $\mathrm{IC}_{50} 1253,99$ ppm warna hijau, aroma agak disukai, dan penerimaan keseluruhan suka.

\section{Saran}

Pembuatan teh herbal matcha daun tenggulun digunakan suhu $60^{\circ} \mathrm{C}$ selama 120 menit dan perlu dilakukan penelitian lebih lanjut mengenai penambahan bahan pangan yang lain pada proses pengolahan teh herbal matcha daun tenggulun untuk menghasilkan teh herbal matcha daun tenggulun dengan kandungan antioksidan yang lebih baik.

\section{DAFTAR PUSTAKA}

Adri, D., dan W. Hersoelistyorini. 2013. Aktivitas Antioksidan dan Sifat Organoleptik Teh Daun Sirsak (Annona muricata Linn.) Berdasarkan Variasi Lama Pengeringan. Jurnal Pangan dan Gizi. Vol.004. No.07. Tahun 2013.

Amanto, B. S., T. N. Aprilia., A. Nursiwi. 2020. Pengaruh Lama Blanching dan Rumus Petikan Daun Terhadap Karakteristik Fisik, Kimia, Serta Sensoris Teh Daun Tin (Ficus carica). Jurnal Teknologi Hasil Pertanian, Vol. XII, No. 1. Februari 2019.

Atmaja, A. I. K. 2011. Uji Aktivitas Antioksidan Ekstrak Etanol Buah Psidium guajava L., Melaleuca Leucadendron L., Capsicum frutescens L., Anethum graveolens L. Dengan Metode DPPH Beserta Penerapan Kadar Fenolik Totalnya. Skripsi. Surakata: Universitas Muhammadiyah Surakarta.

Eniek, K. 1997. Identifikasi, Struktur Anatomi dan Studi Pendahuluan Golongan Senyawa Kimia Daun Pelengkap Bumbu Lawar dan Betutu. F. Mipa. Universitas Udayana. Jimbaran

Felicia, N. I.W.R.Widarta., N.L.A.Yusasrini 2016. Pengaruh Ketuaan Daun dan Metode Pengolahan Terhadap Aktivitas Antioksidan Serta
Karakteristik Sensoris Teh Herbal Bubuk Daun Alpukat (Persea americana Mill). Skripsi Program Study Ilmu dan Teknologi Pangan.Universitas Udayana. Bukit Jimbaran.

Fellow, P.J. 1990. Food Processing Technology. Principle and Practice. Ellis Horwood. New York.

Gromer, T. 2009. The Secret of Japanese Tea. AIYA Europe GmbH,Jerman.

Heyne, K. 1987. Tumbuhan Berguna Indonesia II, Edisi I, Badan Penelitian dan Pengembangan Kehutaan, Departemen Kehutanan, Jakarta.

Indarwati, D. 2015. Aktivitras Antioksidan dan Total Fenol Seduhan Teh Herbal Daun Pacar Air ( Impatiens balsamina L.) Dengan Variasi Metode Pengeringan dan Konsentrasi. Naskah Publikasi Program Studi Pendidikan Biologi. Fakultas Keguruan dan Ilmu Pendidikan. Universitas Muhammadiyah Surakarta.

Jeong, S. M., S. Y. Kim., D. R. Kim., S. C. Jo., K. C. Nam., D.U.Ahn dan S. C. Lee. 2004. Effect of heat treatment on the antioxidant activity of extracts from citrus peels. Journal of Agricultural and Food Chemistry. 52:3389-3393.

Kusuma, I. G. N. S., I. N. K. Putra., L. P. T. Darmayanti. 2019. Pengaruh Suhu Pengeringan Terhadap Aktivitas Antioksidan Teh Herbal Kulit Kakao ( Therobroma cacao L.). Jurnal Ilmu dan Teknologi Pangan. Vol. 8, No.1, 85-93, Maret 2019.

Liliana, W. 2005. Kajian Proses Pembuatan Teh Herbal dari Seledri (Apium graveolens L). Fakultas Teknologi Pertanian. IPB.

Lingganingrum. F. S., E.S.Maharini. 2018. Teh Hijau dari Daun Ashitaba: Aktifitas Antioksidan dan Mutusensori. Prosiding Seminar Nasional Teknik Kimia "Kejuangan" ISSN 1693-4393 Pengembangan Teknologi Kimia untuk Pengolahan Sumber Daya Alam Indonesia Yogyakarta, 12 April 2018. 1693-4393.

Nathaniel A. N., I. N. K. Putra., A. A. I. S. Wiadnyani. 2019. Pengaruh Suhu dan Waktu Pengeringan Terhadap Aktivitas Antioksidan dan Sifat Sensoris Teh Herbal Celup Daun Rambusan ( Passiflora foetida L.). Program Studi Ilmu dan Teknologi Pangan. Fakultas Teknologi Pertanian.

Preddy, V. R. 2014. Processing and Impact on Antioxidants in Beverages, Academic press, Massachusetts.

Rahman A., R. Utari. 2006. Aktivitas Antioksidan, Kandungan Fenolat Total dan Kandungan Flavonoid Total Ekstrak Etil Asetat Buah Mengkudu Serta Fraksi-Fraksinya. Majalah Farmasi Indonesia. 17:137-13.

Rahmawati, N., A.Fernando, dan Wachyuni. 2013. Kandungan Fenolik dan Aktivitas Antioksidan Ekstrak Daun Gambir Kering ( Uncaria gambir hunter roxb). J. Ind. Che. Acta. 4(1):1-6

Riansyah A., A. Supriadi., R. Nopianti. 2013. Pengaruh Perbedaan Suhu dan Waktu Pengeringan Terhadap 
Karakteristik Sepat Siam (Trichogaster pectoralis) Dengan Menggunakan Oven. Jurnal Fishtech. Vol II, No 1,

Sakanaka, S., Y. Tachibana, dan Y. Okada. 2013. Preparation and antioxidant properties of extracts of japanese persimo leaf tea (kakinocha-cha). Food chemistry. 89:569-575.

Sari. D. K., D. R. Affandi., S. Prabawa. 2020. Pengaruh Waktu dan Suhu Pengeringan Terhadap Karakteristik The Daun Tin (Ficus Carica L.)

Sekarin, G. A. 2011. Kajian Penambahan Gula dan Suhu Penyajian Terhadap Kadar Total Fenol, Kadar Tanin (Katekin) dan Aktivitas Antioksidan pada Minuman The Hijau (Camellia sinensis L.). Skripsi Jurusan Teknologi Hasil Pertanian. Universitas Sebelas Maret. Surakarta.

Setyamidjaja, D. 2000. Teh: Budi Daya dan Pengolahan Pascapanen. Penerbit Kanisius, Yogyakarta.

Simamora, A. C. Y., N. L. A. Yusasrini., I. N. K. Putra. 2020. Pengaruh Jenis Pelarut Terhadap Aktivitas Antioksidan Ekstrak Daun Tenggulun (Protium javanicum Burm.F) Menggunakan Metode Maserasi. Program Studi Ilmu dan Teknologi Pangan. Fakultas Teknologi Pertanian.

Soekarto, S.T. 1985. Penilaian Organoleptik Untuk Industri Pangan dan Pertanian. Bharata Karya Aksara. Jakarta.

Standarisasi Nasional Indonesia (SNI). Teh Hijau.

Sudarmadji, S., B. Haryono, dan Suhardi. 1997. Prosedur Analisis untuk Bahan Makanan dan Pertanian. Liberty, Yogyakarta.
Suhardi. 1997. Analisis Senyawa Polifenol Produk Buah-buahan dan Sayuran Vol.3. Yogyakarta. Laboratorium Kimia-Biokimia Pengolahan Fakultas Teknologi Pertanian Universitas Gadjah Mada, Yogyakarta.

Taib, G., G. Said dan S. Wiraatmadja. 1997. Operasi Pengeringan Pada Pengolahan Hasil Pertanian. Mediyatama Sarana Perkasa, Jakarta.

Topuz, A., C. Dincer, M. Torun, I. Tontul, H. S. Nadeem, A. Haznedar, F. Ozdemir. 2014. Physicochemical Properties of Turkish Green Tea Powder: Effects of Shooting Period, Shading, and Clone. Turkish Journal Of Agriculture and Forestry 38:233-241.

Wahyuningsih, M. 2011. The Efektif Turunkan Berat Badan.

https://health.detik.com/read/2011/01/04/081927/ 1538547/766/teh-efektif-turunkan-berat-badan, (Diakses tanggal 8 Desember 2020)

Widarta I. W. R., I. D. G. M. Permana., A. A. I. S. Wiadnyani. 2018. Kajian Waktu dan Suhu Pelayuan Daun Alpukat dalam Upaya Pemanfaatannya sebagai Teh Herbal. Jurnal Aplikasi Teknologi Pangan 7 (2).

Winarno, F. G. 1995. Kimia Pangan dan Gizi. Gramedia Pustaka Utama, Jakarta.

Widarta, I. W. R., Arnata. I. W. 2017. Ekstraksi Komponen Bioaktif Daun Alpukat dengan Bantuan Ultrasonik Pada Berbagai Jenis dan Konsentrasi Pelarut. Agritech 37(2): 148-157. DOI:10.22146/agritech.10397. 